\title{
NOTE ON GRÜSS TYPE INEQUALITY
}

\author{
JosIP PEČARIĆ AND IVAN PERIĆ
}

Abstract. In this note we prove, using Karamata's estimations of the Chebyshev quotient, Grüss type inequality which improves and generalize the inequality given by Dragomir-Khan.

Mathematics subject classification (2000): 26D15.

Key words and phrases: Grüss type inequality, Karamata's estimations, Chebyshev quotient.

\section{REFERENCES}

[1] D. ANDRICA AND C. BADEA, Grüss' inequality for positive linear functionals, Periodica Math. Hungarica, 19, 2 (1988), 155-167.

[2] M. Biernacki, H. PideK AND C. RYll-NARZEWSKI, Sur une inégalité entre des intégrales definies, Ann. Univ. Mariae Curie-Skolodowska, A4, (1950), 1-4.

[3] S. S. Dragomir And L. Khan, Two discrete inequalities of Grüss type via Polýa-Szegö and Shisha results for real numbers, Tamkang J. of Math. (to appear).

[4] G. GRÜSS, Über das Maximum des absoluten Betrages Von $\frac{1}{b-a} \int_{a}^{b} f(x) g(x) d x-$ $\frac{1}{(b-a)^{2}} \int_{a}^{b} f(x) d x \int_{a}^{b} g(x) d x$, Math. Z. 39, (1935), 215-226.

[5] A. LuPAs, On two inequalities of Karamata, Univ. Beograd, Publ. Elektrotehn. Fak. Ser. Mat. Fiz., No. 602-633, (1978), 119-123.

[6] D. S. Mitrinović, J. E. PeČArić And A. M. FinK, Classical and new inequalities in analysis, Kluwer Academ. Publ., 1993.

[7] J. KARAMATA, Sur certaines inégalités relatives aux quotients et la difference $\int f g$ et $\int f \int g$, Acad. Serbe Sci. Publ. Inst. Math., 2, (1948), 131-145.

[8] J. PEČARIĆ AND B. SAVIĆ, On generalizations of J. Karamata's results and some applications, Zbornik radova AkoV, Beograd, (1984), 245-268. 